\title{
HVMANITAS
}

\section{“Tirano ao Tibre!” Estereótipos de tirania nas “Vidas dos Césares” de Suetónio}

Autor(es): $\quad$ Brandão, José Luís Lopes

Publicado por: Faculdade de Letras da Universidade de Coimbra, Instituto de Estudos

URL

persistente: URI:http://hdl.handle.net/10316.2/27934

DOI: $\quad$ DOI:http://dx.doi.org/10.14195/2183-1718_60_9

Accessed : $\quad$ 26-Apr-2023 15:26:47

A navegação consulta e descarregamento dos títulos inseridos nas Bibliotecas Digitais UC Digitalis, UC Pombalina e UC Impactum, pressupõem a aceitação plena e sem reservas dos Termos e Condições de Uso destas Bibliotecas Digitais, disponíveis em https://digitalis.uc.pt/pt-pt/termos.

Conforme exposto nos referidos Termos e Condições de Uso, o descarregamento de títulos de acesso restrito requer uma licença válida de autorização devendo o utilizador aceder ao(s) documento(s) a partir de um endereço de IP da instituição detentora da supramencionada licença.

Ao utilizador é apenas permitido o descarregamento para uso pessoal, pelo que o emprego do(s) título(s) descarregado(s) para outro fim, designadamente comercial, carece de autorização do respetivo autor ou editor da obra.

Na medida em que todas as obras da UC Digitalis se encontram protegidas pelo Código do Direito de Autor e Direitos Conexos e demais legislação aplicável, toda a cópia, parcial ou total, deste documento, nos casos em que é legalmente admitida, deverá conter ou fazer-se acompanhar por este aviso. 
humanitas

\section{Vol. LX}

IMPRENSA DA UNIVERSIDADE DE COIMBRA

COIMBRA UNIVERSITY PRESS 


\title{
TIRANO AO TIBRE! ESTEREÓTIPOS DE TIRANIA NAS VIDAS DOS CÉSARES DE SUETÓNIO*
}

\author{
José Luís Lopes Brandão \\ Universidade de Coimbra \\ iosephus@ci.uc.pt
}

\section{Resumo}

Neste estudo, procura-se explorar a aplicação aos imperadores, por parte de Suetónio ou das suas fontes, dos topoi habituais da descrição dos tiranos, como arrogância, crueldade, sumptuosidade, devassidão, avidez de dinheiro ou propensão para a espoliação dos súbditos. Por conseguinte, a preocupação em assimilar a vida de imperadores como Tibério, Calígula ou Nero às características dos tiranos pode estar na origem de relatos extravagantes, baseados em boatos infundados.

Palavras-chave: biografia, Império Romano, Césares, Suetónio, tirania.

\section{Abstract}

In this article we try to explore topoi used (by Suetonius or his sources) in the characterization of tyrants and the way vices, such as arrogance, cruelty, luxury, debauchery, greediness or propensity to spoil citizens, fix into the shape of Roman emperors. So the aim to assimilate the life of emperors like Tiberius, Caligula or Nero to the tyrants' features can explain the origin of some extravagant tales based upon unfounded rumours.

Keywords: biography, Roman Empire, Caesars, Suetonius, tyranny.

${ }^{*}$ Uma versão abreviada deste artigo foi apresentada no VI Congresso Internacional da APEC "Identidade e Cidadania, da Antiguidade aos nossos dias" (Faculdade de Ciências Sociais e Humanas da Universidade Nova de Lisboa, 18-21 de Outubro de 2006). 
Os exemplos usados por Suetónio nas Vidas dos Césares para documentar determinados vícios, bem como os termos em que estes são expressos, parecem inscrever-se no discurso tradicional contra a tirania. Somos confrontados com a evidência de que, na descrição directa ou indirecta dos piores imperadores, são usados lugares-comuns normalmente conotados com a ideia de tirano, tal como é apresentado no teatro, na filosofia, na história, nos discursos forenses, nas escolas de retórica. Esta coincidência levanta a suspeita de que muitos exempla que ilustram as species das Vidas poderão ser decalcados das atitudes que se supõem existir num monarca à maneira oriental, mais por associação de ideias ou de caracteres do que por evidência histórica.

A descrição tradicional dos tiranos helenísticos aponta para uma riqueza proverbial, associada a sumptuosidade, rapacidade e uma felicidade decorrente do facto de poder fazer impunemente o que deseja ${ }^{1}$. A fuga à norma manifesta-se na arrogância e aspirações a um culto divino, exagerada crueldade no castigo dos súbditos e na eliminação de possíveis rivais, parricídio e assassínio de familiares próximos, prepotência no domínio sexual, manifesta através do abuso de mulheres e homens livres.

Superbia, crudelitas, auaritia, libido tornam-se elementos convencionais ${ }^{2}$, do género dos usados, por exemplo, por Tito Lívio na descrição do famoso Tarquínio-o-Soberbo (1.49 ss), por demais arrogante e cruel, ou de Jerónimo, tirano de Siracusa (24.5.3-6), de quem se refere, além de arrogância e crueldade, outros elementos significativos, como o uso de trajes sumptuosos, a ostentação de um corpo de guarda-costas e a propensão para uma libido sem precedentes ${ }^{3}$. São termos igualmente usados por Cícero, para classificar as actividades de Verres, Clódio, Pisão, Gabínio ou António ${ }^{4}$, e também por uma das fontes de Suetónio, o naturalista Plínio, nos elementos biográficos que sobre os imperadores transmite ${ }^{5}$.

\footnotetext{
${ }^{1}$ Vide J. F. McGlew 1993: 26 ss.

${ }^{2}$ Crueldade, avidez e violência sexual são elencados, como traços típicos do tirano, em Quint. Ded. 329.Vide R. Tabacco 1985: 87 e 131.

${ }^{3}$ Vide J. R. Dunkle 1971: 16-17.

${ }^{4}$ Como demonstra J. R. Dunkle 1967: 151-171.

${ }^{5}$ Como demonstra F. Oliveira 1995: 67-84. Vide também F. Oliveira 1997: 119-138.
} 
Entre as características dos tiranos destaca-se, pois, a crudelitas ou saevitia ${ }^{6}$. O facto de, em César, o espírito tirânico não aparecer associado à saeuitia, mas mitigado por uma assinalável clementia ${ }^{7}$, torna o julgamento de Suetónio sobre o ditador mais equilibrado. Já em Tibério, Calígula, Nero e Domiciano o espírito tirânico é agravado pela crueldade ${ }^{8}$. A atrocitas, termo referido nas Vidas de Tibério, Calígula, Nero e Domiciano ${ }^{9}$, indica situações assaz adversas da fortuna ${ }^{10}$, mas também acções e palavras hediondas dos biografados ${ }^{11}$. A falta de moderação é ainda expressa pela immanitas dos actos de Calígula e do comportamento e da própria natura de $\mathrm{Nero}^{12}$. Os sinais da tirania estão inscritos na natureza e no carácter, pelo que se

${ }^{6} \mathrm{~J}$. R. Dunkle 1971: 14-15 nota que, a partir dos últimos anos de Cícero, o termo crudelitas começa a ser substituído por saevitia na descrição popular do tirano. Acrescenta que o último implica conotações de histerismo e sadismo maníaco, uma vez que primariamente se refere à ferocidade dos animais selvagens. Em Suetónio, prevalece saeuitia.Vide R. Tabacco 1985: 89-116.

7 Jul. 75.1: Moderationem uero clementiamque cum in administratione tum in uictoria belli ciuilis admirabilem exhibuit. As citações de Suetónio serão feitas com indicação da abreviatura da Vida em causa, sem menção do nome do autor, visto ser ele o principal objecto de análise neste estudo.

${ }^{8}$ Tib. 57-62; Cal. 27-33; Nero 33-38; Dom. 10-11. Vide J. Gascou 1984: 723 e 725 .

9 Nas suas variantes de nome, adjectivo e advérbios: vide Index de A. A. Howard / C. N. Jackson 1922.

${ }^{10}$ A atrocitas aparece referida à má fortuna que fez com que Tibério fosse o herdeiro de Augusto (Tib. 23), à condição dos tempos de Tibério e Caligula (Tib. 48.1; Cal. 6.2).

${ }_{11}$ Tib. 58: atrocissime exercuit; Tib. 59.1: ita saeue et atrociter factitauit; Tib. 75.1: (...) exacerbati super memoriam pristinae crudelitatis etiam recenti atrocitate; Cal. 12.2: (...) liberto, qui ob atrocitatem facinoris exclamauerat, confestim in crucem acto; Cal. 29.1: immanissima facta augebat atrocitate uerborum; Cal. 48.1: Prius quam prouincia decederet, consilium iniit nefandae atrocitatis legiones (...) contrucidandi; Nero 34.4: Adduntur his atrociora nec incertis auctoribus; Dom. 11.1: (...) ut non aliud iam certius atrocis exitus signum esset quam principii lenitas; Dom. 11.3: deinde atrocitate poena conterritus, ad leniendam inuidiam intercessit his uerbis.

${ }_{12}$ Cal. 29.1: immanissima facta; Nero 7.2: et fidem somnio breui Nero fecit prodita immanitate naturae; 43.1: Initio statim tumultus multa et immania, uerum non abhorrentia a natura sua creditur destinasse. 
manifestam nas acções e nas palavras espontâneas, o principal objecto de estudo da biografia segundo Plutarco (Alex. 1).

As manifestações de crueldade do tirano começam dentro do círculo familiar palaciano e alargam-se, depois, numa espiral de progressiva arbitrariedade. É esta a gradação que Suetónio estabelece no horror dos crimes de Tibério ${ }^{13}$, Calígula ${ }^{14}$ e Nero. No caso do último, os parricidia et caedes começam com o pater adoptivo (Nero 33.1), continuam com Britânico (Nero 33.2-3), a mãe (Nero 34.1-4), a tia (Nero 34.5), as esposas (Nero 35.1-3), estendem-se, de seguida, à morte de outros familiares ${ }^{15}$ e próximos ${ }^{16}$, depois, aos crimes contra pessoas de fora da casa imperia $1^{17}$, mais à frente a um leque arbitrário de vítimas e de $\operatorname{pretextos}^{18} \mathrm{e}$, depois de uma notável progressão, vão culminar no atentado contra o povo e contra os muros da patria (Nero 38$)^{19}$ - termo raro em. Suetónio que retoma a noção de parricida, com que o biógrafo inicia o relato, como observa Bradley ${ }^{20}$. A narrativa do desastre assenta em rumores tendenciosos, pois não só apresenta como inquestionável a culpa do imperador no incêndio de 64 , suspeita que Tácito põe em dúvida (Ann. 15.38.1.), como visa ainda acentuar o horror do crime com a indicação de que Nero, em traje de cena, assistiu à castástrofe a cantar um poema sobre a queda de Tróia episódio que o historiador considera apenas um dos boatos que corriam (Nero 38.2. Cf.Tac. Ann. 15.39.3).

${ }^{13}$ Sobre quem esta rubrica começa o odium aduersum necessitudines (Tib. 50.1).

${ }^{14}$ A descrição da crueldade começa com manifestações de leviandade e frieza em relação a propinqui amicique (Cal.26).

${ }^{15}$ Nero 35.4: Nullum adeo necessitudinis genus est, quod non scelere perculerit.

${ }^{16}$ Nero 35.4: (..) similiter [inter] ceteros aut affinitate aliqua aut propinquitate coniunctos; in quibus Aulum Plautium iutenem, quem cum ante mortem per uim conspurcasset.

${ }^{17}$ Nero 36.1: Nec minore saeuitia foris et in exteros grassatus est.

${ }^{18}$ Nero 37.1: Nullus posthac adhibitus dilectus aut modus interimendi quoscumque libuisset quacunque de causa.

${ }^{19}$ Vide J. Gascou 1984: 697-700.

${ }^{20}$ Nero 38.1: Sed nec populo aut moenibus patriae pepercit. Vide K. R. Bradley 1978: 227-228; B. H. Warmington 1999: 72. Sobre a mesma associação em Quint. Decl. 322, vide R. Tabacco 1985: 125-126 n.351.

${ }^{21}$ Cf. Quint. Decl. 322.Vide R. Tabacco 1985: 111. 
Os crimes contra a família denotam uma total falta de pietas. A crueldade levada até ao parricídio, quando está em jogo a conquista do poder, ocorre nas declamações das escolas de retórica latinas ${ }^{21}$. Suetónio procura tornar Nero cúmplice na morte de Cláudio ${ }^{22}$, ao passo que, no relato da morte deste imperador ( $\mathrm{Cl}$. 44), não fora insinuada a cumplicidade do sucessor, mas somente a acção de Agripina. A ideia de que o tirano é, por natureza, parricida tem um modelo trágico em Édipo, mas também em Altémenes, filho de Catreu, que, no que toca à fuga a um oráculo e à morte do pai, cumpre um destino semelhante ao do filho de Laio $^{23}$. De resto, outras conexões míticas e trágicas são evocadas pelo biógrafo para caracterizar o comportamento de Nero a propósito do matricídio: divulgam-se escritos que o associam a Orestes e Alcméon (Nero 39.2), e ele próprio se diz perseguido pelas Fúrias (Nero 34.4).

R. Mayer encontra na narrativa do assassínio de Popeia, com um pontapé, quando ela se encontrava grávida (Nero 35.3), uma tentativa de assimilar Nero a um tirano, nomeadamente a Periandro. Este, que apresentava no seu curriculum outras semelhanças com Nero (como o incesto e o projecto de abertura de um canal no Istmo de Corinto), terá matado, segundo Diógenes Laércio (1.94), a esposa grávida, num momento de cólera, com um pontapé. Mas a comparação do passo de Suetónio com a versão de Tácito (Ann.16.6) e de Díon Cássio (62.27) indicia um acidente e não uma intenção deliberada de $\mathrm{Nero}^{24}$.

A crueldade dos tiranos manifesta-se no requinte das torturas, de que é exemplo o facto de Tibério, post longa et exquisita tormenta, fazer precipitar os condenados do alto de um rochedo em Cápreas (local que se tornou turístico, como mostra o biógrafo ${ }^{25}$; ou o castigo exemplar, de modo a dissuadir as aproximações furtivas ao refúgio do tirano, do pescador de Cápreas que sobe as escarpas para oferecer a Tibério o melhor peixe que pescara (Tib. 60); ou a invenção de um novo tipo de suplício, que consistia em mandar ligar os órgãos genitais das vítimas depois de as ter feito beber grande quantidade de vinho (Tib. 62.2). Também

\footnotetext{
${ }^{22}$ Cuius necis non auctor, at conscius fuit (Nero 33.1).

${ }^{23}$ Cf. Apollod. 3.2.1-2; D.S. 5.59.

${ }^{24}$ R. Mayer 1982: 248-249.

${ }^{25}$ Tib. 62.2: Carnificinae eius ostenditur locus Capreis.
} 
Domiciano, que parece ter uma admiração especial por Tibério (Dom. 20), inventa um tipo de tortura semelhante, que consiste em chegar fogo aos órgãos sexuais (Dom. 10.5).

Como evidência do grau da crueldade de Gaio é narrado o facto de obrigar os próprios pais a assistirem à morte dos filhos ou de mandar cortar a língua a um cavaleiro para que, lançado às feras, não proclame a sua inocência (Cal. 27.4). Também a acusação de que Calígula costumava, durante os banquetes, assistir a processos que implicavam tortura, ou à decapitação de condenados (Cal. 32.1) coincide com um dos temas retóricos favoritos dos declamadores ${ }^{26}$. Vitélio, cujos vícios predominantes são a gula e a crueldade (Vit. 13.1), manda executar um condenado à sua frente (Vit. 14.2.) porque 'uelle se' dicens 'pascere oculos' («queria dar alimento aos olhos») e contempla a luta contra os partidários de Vespasiano e o incêndio do Capitólio no meio de um banquete (Vit. 15.3), o que parece conotar este imperador também com o gostos de Nero. De resto, Vitélio é associado pelo biógrafo aos piores dos Júlio-Cláudios e aos seus vícios (Vit. 4). A tendência de Nero para transformar a crueldade em espectáculo manifesta-se também no facto de correr o boato de que quereria dar homens vivos a comer a um polyphagus egípcio, habituado a devorar tudo o que se the dava (Nero 37.2).

Para salientar a ligação dos imperadores visados aos vícios tirânicos, Suetónio adopta a estratégia de estabelecer uma gradação na crueldade, de modo a demonstrar que, no final do processo, ninguém se podia sentir seguro sob o domínio de tiranos de uma crueldade astuta e imprevisível, como se diz a propósito de Domiciano ${ }^{27}$, mas também completamente arbitrária e implacável na aplicação das execuções, como se diz de Nero, Galba e Vitélio ${ }^{28}$.

Característica frequente dos tiranos, e muitas vezes motivadora de actos de crueldade, é a auaritia. A avareza de Tibério é apresentada em

\footnotetext{
${ }^{26}$ Cf. Sen. Con. 9.2; Liv. 39.42ss; Cic. Sen. 42.

${ }^{27}$ Erat autem non solum magnae, sed etiam callidae inopinataeque saeuitia (Dom. 11.1).

${ }^{28}$ Nullus posthac adhibitus dilectus aut modus interimendi quoscurnque libuisset quacumque de causa (Nero 37.1); quosdam claros ex utroque ordine uiros suspicione minima inauditos condemnauit (Gal. 14.3); Pronus uero ad cuiuscumque et quacumque de causa necem atque supplicium (Vit. 14.1).
} 
gradação: de pecuniae parcus ac tenax (Tib. 46), antes de chegar ao principado, progride, depois, para a extorsão ${ }^{29}$. Este modelo de evolução no sentido das rapinae adapta-se também a Calígula, Nero e Domiciano (Cal. 38.1; Nero 32.1; Dom. 12.1), ao ponto de chegarem a extremos de ridículo. Entre os diversos exemplos das rapinae de Nero, conta-se que, enquanto o imperador cantava, reparou que na assistência estava uma matrona vestida de púrpura, contra a lei; prontamente a mandou despojar do vestido e dos bens ${ }^{30}$. Como ponto culminante desta prática de extorsão de Domiciano, Suetónio atesta o excesso de rigor posto na colecta do Iudaicus fiscus com o testemunho pessoal (interfuisse me adulescentulum memini) da impressão que lhe causara a inspecção de um judeu nonagenário, na presença de frequentissimum consilitum, para averiguar se era circuncidado (Dom. 12.2) ${ }^{31}$. O lupanar que Calígula mandara supostamente instalar no palácio, onde se prostituíam matronas e jovens livres para beneficio do cofre imperial (Cal. 41.1), parece servir de modelo para o mesmo atrevimento atribuído a Cómodo na História Augusta ${ }^{32}$.

Tal vício associa-se também à impietas quando está em causa o roubo dos templos, outro crime típico do tirano retórico ${ }^{33}$ perpetrado por Nero e, já antes, por César ${ }^{34}$. De resto, a impietas, manifesta no desprezo pela religião tradicional, é uma constante nos maus imperadores ${ }^{35}$. A descrição

${ }^{29}$ procedente mox in tempore etiam ad rapinas conuertit animum (Tib. 49.1).

${ }^{30}$ Nero 32.3: Quin etiam inter canendum animaduersam matronam in spectaculis uestita purpura cultam demonstrasse procuratoribus suis dicitur detractamque ilico non ueste modo, sed et bonis exuit. J. Gascou 1984: 706 faz notar, neste exemplo, a passagem sub-reptícia do rumor, indicado por dicitur, ao facto indiscutível (começa por usar o infinitivo demonstrasse, para terminar com o perfeito do indicativo exuit).

31 Suetónio faz referência à taxa da didracma, que os Judeus pagavam para o templo de Jerusalém e que, depois da destruição deste, no ano 70, passaram a pagar para o templo de Júpiter Capitolino, o que lhes dava o direito de praticarem livremente a sua religião: cf. J. BJ 7.6.6; D.C. 66.7.2.

${ }^{32}$ Mulierculas formae scitioris ut prostibula mancipia per speciem lupanarium et ludibrium pudicitiae contraxit (Hist.Aug. Com. 2.8).Vide G. Porta 1975: 166-168.

${ }^{33}$ Cf. Quint. Ded. 329; Sen. Con. 5.8; 9.4; Quint. Inst. 3.6.78.

34 Nero 32.4. Cf. Jul. 54.3.

35 Sobre o desprezo ou negligência dos deuses e dos auspícios: Jul. 59; Jul 81.4; Tib. 69.1; Cal. 51.1; Nero 56; Vit. 11.2 e 15.3. Atitudes impias: Nero 32.4; Tib. 61.5 . 
retórica do tipo tirânico que delapida o património para satisfazer os seus apetites desmedidos e depois progride para a espoliação dos cidadãos e dos templos encontra fundamento em Platão ${ }^{36}$.

Se em Tibério, e, de modo semelhante, em Galba (Gal. 12.1), as rapinae são consequência da avareza, em Calígula, Nero e Domiciano são resultado do esbanjamento ${ }^{37}$. Em oposição à mesquinhez de Tibério, Calígula, em apenas um ano, desbarata as imensas riquezas acumuladas pela avareza do velho imperador (Cal.37.3). Por esta atitude de Calígula, Nero apresenta-se como seu admirador ${ }^{38}$. Estes dois imperadores tornam-se arautos da inversão de valores, quando elogiam a sumptuosidade e o desbaratamento de recursos como as atitudes mais recomendáveis num príncipe $^{39}$. A sumptuosidade é, assim, mais um traço típico dos tiranos.

O cúmulo da extravagância de Nero é a dispendiosa construção da Domus Aurea ${ }^{40}$, cuja descrição parece assentar nos tópicos da diatribe contra a sumptuosidade ${ }^{41}$. No vestíbulo, foi erigido um colosso de 120 pés com o rosto do imperador, posteriormente dedicado ao Sol por Ves-

${ }^{36}$ Pl. R. 9.573 d-575; cf. Arist. Pol. 1305 b 39 ss. Vide R. Tabacco 1985 : 28-29, 118 n. 327.

${ }^{37}$ Cal. 38.1: Exhaustus igitur atque egens ad rapinas conuertit animum; Nero 32.1: iam exhaustus et egens... calumniis rapinisque intendit animum; Dom. 12.1: Exhaustus operum ac munerum inpensis stipendioque, quod adiecerat... nihil pensi habuit quin praedaretur omni modo.

${ }^{38}$ Nero 30.1: Laudabat mirabaturque auunculum Gaium nullo magis nomine, quam quod ingentis a Tiberio relictas opes in breui spatio prodegisset.

${ }^{39} \mathrm{Cal}$.37.1: Nepotatus sumptibus ommium prodigorum ingenia superauit... 'aut frugi hominem esse oportere' dictitans 'aut Caesarem'; $37.22 .$. nihil tam efficere concupiscebat quam quod posse effici negaretur; Nero 30.1: Dititiarum et pectiniae fructum non alium putabat quam profusionem, 'sordidos ac deparcos esse quibus impensarum ratio constaret, praelautos uereque magnificos qui abuterentur ac perderent'; 30.2: Quare nec largendi nec absumendi modum tenuit.

${ }^{40}$ Nero 31.1: Non in alia re tamen damnosior quam in aedificando domum a Palatio Esquilinas usque fecit.

${ }^{41}$ Nero 31.2. Cf. Tac. Ann. 15.42-43. M. P. Morford 1968: 158-179 vê nas descrições da Domus Aurea, em Suctónio e Tácito (Ann. 15.42-43), distorções resultantes da linguagem retórica das declamationes - a diatribe contra a luxuria. $\mathrm{M}$. Blaison 1998: 617-624 mostra que a descrição de Suetónio não corresponde à realidade, mas é uma ekphrasis de uma morada sumptuosa, de acordo com uma tradição fixada desde os poemas homéricos. 
pasiano, e que era reprovável, segundo Plínio, por ser feito no apetecido bronze de Corinto ${ }^{42}$. Não era ainda a representação de uma divindade $^{43}$, mas o facto de ser a primeira de várias estátuas colossais de imperadores salientava a arrogância dos inuidiosa atria regis a que se refere Marcial (Spect. 2.3). O excesso não se manifestava só no luxo do palácio. Tácito (Ann. 15.42.1) considera até que a ornamentação é normal para uma morada luxuosa; o que o impressiona é a amplidão e diversidade dos espaços abertos. A aristocracia romana tinha esplêndidas casas de campo fora de Roma. Mas a Domus Aurea era a realização da fantasia de um tirano: uma uilla no centro da cidade, motivadora de indignação. Aparecem inscrições a censurar o exagero narcisista deste palácio, como mais tarde acontecerá com a profusão de arcos construídos por Domiciano ${ }^{44}$. Não se pode dizer que pretendesse ser morada de um deus ${ }^{45}$; o próprio imperador afirmava que "finalmente começava a habitar como um homem», talvez para evitar uma insinuação de insolência, que o tornaria mais odioso perante a moralidade senatoria ${ }^{46}$. Mas o palácio estava amaldiçoado pela lembrança do recente desastre - o incêndio de 64 - e pelas expropriações que o superbus ager teria implicado, como assinala Marcial (Spect. 2.8), fazendo talvez eco da propaganda flaviana ${ }^{47}$. Para o biógrafo, a construção

${ }^{42}$ Plin. Nat. 34.45; 34.48; 34.82. Cf. Mart. Spect 2.1.Vide F. Oliveira 1992: 124; 181; 183.

${ }^{43}$ Ao contrário da opinião de M. Levi 1973: 221, para quem o colosso é uma estátua do Sol com o rosto de Nero, Plínio e Suetónio apresentam-no como um simples retrato de Nero, sem referência a raios. Plínio (Nat. 34.45) diz que foi dedicado ao Sol depois que os crimes (scelera) do imperador foram condenados. No tempo dos Flávios, Marcial (1.70.7) refere miri vadiata colossi; Herodiano (1.15.9) refere-se à representação do Sol, mas já no tempo de Cómodo. Vide K. Bradley 1978: 289-290.

${ }^{44}$ Roma domus fiet: Veios migrate, Quirites, / si non et Veios occupat ista domus (Nero 39.2). Ianos arcusque cum quadrigis et insignibus triumphorum per regiones urbis tantos ac tot extruxit, ut cuidam Graece inscriptum sit: arci-jogo de palavras com ari no sentido de 'arcos' (latim vulgar, em vez de arcus) ou de 'basta' (em grego).

${ }^{45}$ Como pretende H.-P. L'Orange 1942: 68-100.

${ }^{46}$ Nero 31.2: Eius modi domum cum absolutam dedicaret, hactenus comprobanit, ut se diceret 'quasi hominem tandem habitare coepisse'.

${ }^{47}$ Abstulerat miseris tecta superbus ager. Vide A. Aiardi 1978: 99. Segundo M. Morford 1968: 158-167, a construção não terá implicado tantas expropriações como as fontes sugerem. 
da Domus aurea é apresentada como uma motivação para o maior crime imputado a Nero: o incêndio de Roma (Nero 38.1). Além disso, as iniciativas deste imperador em retirar gratuitamente os cadáveres e os escombros e de não permitir que ninguém se acercasse dos restos dos seus bens medida compreensível, dado o perigo de derrocadas - é distorcida e transformada numa estratégia para the facilitar a pilhagem ${ }^{48}$.

Também a Augusto era apontado o gosto por móveis de luxo e vasos coríntios (Aug. 70.2). Mas, neste caso, Suetónio procura absolvê-lo da culpa, com o argumento de que ele afastou a lautitiarum inuidia com a atitude posterior (Aug. 71.1), onde predominava a continentia ${ }^{49}$. Percebe-se uma defesa do fundador do principado face aos topoi da diatribe contra os tiranos: ao invés de construções luxuosas, a sóbria habitação de Augusto (Aug. 72.1); ao invés da profusão de estátuas e pinturas, o ornamento simples das casas de campo com áleas, jardins e objectos de antiquária, como ossos gigantescos (Aug. 72.3); ao invés das mesas caras, leitos requintados, vestuário e calçado exóticos, a parsimonia do mobiliário e das roupas de fabrico caseiro (Aug. 73). Também Tito sabe moderar-se e transforma as prolongadas orgias em banquetes mais agradáveis que dispendiosos ${ }^{50}$.

Outro traço dos tiranos é uma libido exacerbada que leva ao abuso de mulheres e homens livres. A invectiva de tipo sexual era um lugar-comum, como demonstram os ataques de que César foi alvo da parte dos seus inimigos políticos (Jul. 49-52). A impudicitia e as libidines de César são expostas nos versos dos soldados no triunfo da Gália (Jul. 49.4; 51). Marco António acusa Augusto de abuso de mulheres livres (Ang. 69).

${ }^{48}$ Nero 38.3: Ac ne non hinc quoque quantum posset praedae et manubiarum inuaderet, pollicitus cadauerum et ruderum gratuitam egestionem nemini ad reliquias rerum suarum adire permisit. Tac. Ann. 15.43.2 coloca a promessa de remover escombros e cadáveres entre as medidas louváveis de Nero, o que sugere que tanto Tácito como Suetónio usaram a mesma fonte, que era favorável. Mas Suetónio manipula o material de modo a reforçar o retrato negativo; vide K. R. Bradley 1978: 235; B. H. Warmington 1999: 73.

${ }^{49}$ Aug. 72.1: In ceteris partibus uitae continentissimus constat ac sine suspicione ullius uitii.

${ }^{50}$ Tit. 7.1: ad mediam noctem comissationes; 7.2: Conuituia instituit iucunda magis quam profusa. 
As virgens são as vítimas preferenciais do tirano retórico ${ }^{51}$, como demonstra a conhecida história de Virgínia, que o próprio pai matou para, assim, a livrar da concupiscência do decênviro Ápio Cláudio ${ }^{53}$. Também Augusto não se livra desta pecha, pois diz-se que gostava de desflorar virgens que a própria esposa lhe forneceria ${ }^{54}$. No mesmo plano se inclui a alegada violação da vestal Rúbria por $\mathrm{Nero}^{55}$.

Suetónio, que desde o princípio apresenta Tibério determinado pelos genes dos Cláudios ${ }^{55}$ e recorda até o crime de Ápio Cláudio (Tib. 2.2), explora os rumores, segundo os quais, este imperador, depois de se retirar para a ilha de Cápreas, se entrega, sem peias, aos vícios que antes dissimu$\operatorname{lara}^{56}$. O secretismo da ilha favorece a criação de mitos picantes:

Secessu uero Caprensi etiam sellaria excogitauit, sedem arcanarum libidinum, in quam undique conquisiti puellarum et exoletorum greges monstrosique concubitus repertores, quos spintrias appellabat, triplici serie conexi, in uicem incestarent coram ipso, ut aspectu deficientis libidines excitaret. Cubicula plurifariam disposita tabellis ac sigillis lasciuissimarum picturarum et figurarum adornauit librisque Elephantidis instruxit, ne cui in opera edenda exemplar impetratae schemae deesset. In siluis quoque ac nemoribus passim Venerios locos commentus est prostantisque per antra et cauas rupes ex utriusque sexus pube Paniscorum et Nympharum habitu, quae palam iam et uulgo nomine insulae abutentes Caprineum dictitabant. ${ }^{57}$

«No seu retiro em Cápreas, inventou também um quarto com divãs, sede das suas lascívias secretas, no qual, bandos de moças e rapazes perver-

${ }^{51}$ Cf. Quint. Decl.345; Sen. Con. 2.5; 9.4.Vide R. Tabacco 1985: 118 ss.

${ }^{52}$ Liv. 3.48.

${ }^{53}$ Aug. 71.1. C. D.C. 2.5.

${ }^{54}$ Vestali uirgini Rubriae uim intulit (Nero 28.1). O episódio da vestal Rúbria não aparece em outras fontes, à excepção de Aurélio Victor (Caes. 5.11), o que é suspeito, dada a gravidade de tal acto.Vide R. Verdière 1975: 7; R. Martin 1991: 144; B. H. Warmington 1999: 54.

${ }^{55}$ Ex hac stirpe Tiberius Caesar genus trahit, $e<t>$ quidem utrumque (Tib. 3.1).

${ }^{56}$ Ceterum secreti licentiam nanctus et quasi ciuitatis oculis remotis, cuncta simul uitia male diu dissimulata tandem profudit: de quibus singillatim ab exordio referam (Tib. 42.1).

57 Tib. 43. A referência aos Pãs e ninfas bem como à alcunha de 'caprino' sugere que a sexualidade de Tibério é inspirada na dos Sátiros. Mas Tibério parece criar à sua volta um teatro pornográfico e mitológico, consonante com o gosto da época, como sugerem F. Dupont et T. Éloi 2001: 293-304. Vide J. L. Brandão 2005: 92-94. 
tidos, recolhidos de toda a parte, e os inventores de monstruosas uniôes, aos quais chamava spintriae, encadeados em grupos de três, se pudessem prostituir alternadamente à sua frente, para que, ao olhar, ele excitasse os seus desejos em declínio. Adornou alcovas, dispostas em vários sítios, de quadros e estatuetas com pinturas e esculturas de extrema devassidão e guarneceu-os de livros de Elefântis, para que a ninguém faltasse, ao executar o serviço, o modelo da atitude exigida. Também, nas matas e nos bosques, teve a ideia de distribuir, por aqui e por ali, sítios para os prazeres de Vénus e, por antros e grutas, os que se prostituíam, de entre a juventude de um e outro sexo, em traje de pequenos Pãs e Ninfas. Por esta razão, às claras e jogando de forma vulgar com o nome da ilha, repetidas vezes the chamavam 'caprino'»

Tácito (Ann. 6.1) lembra que se trata de crimes tirânicos (more regio) sobre a juventude de nascimento livre. Perante a monstruosidade dos factos, o próprio biógrafo parece manifestar alguma incredulidade: Maiore adhuc ac turpiore infamia flagranit, uix ut referri audiriue, nedum credi fas sit ( Uma má fama ainda maior e mais torpe alastrou a tal ponto que a custo é lícito contar ou ouvir, e muito menos dar-lhe crédito»). Trata-se de prostituição de meninos de tenra idade - os pisciculi que nadavam à volta do imperador, para lhe excitarem os sentidos (Tib. 44.1). Mas o erotismo na piscina inscreve-se num topos da poesia epigramática e na diatribe contra os tiranos, também registado em relação a Domiciano ${ }^{58}$ e, mais tarde, a Heliogábalo (Hist.Aug. Hel. 31.7).

A sedução de mulheres nobres casadas por parte de César e Augusto $^{59}$ não assume os tons negros do ultraje às matronas ilustres perpetrado por Tibério ${ }^{60}$, do humilhante escrutínio levado a cabo por Calígula no triclínio (Cal. 36.2), ou das orgias atribuídas a Nero ${ }^{61}$. O abuso de

${ }^{58}$ Cf. Dom. 22. O mesmo motivo figura, de forma galante, em Mart. 4.22. Vide F. Dupont et T. Éloi 2001: 304-306.

59 Jul. 50.1: Pronum et sumptuosum in libidines fuisse constans opinio est, plurimasque et illustres feminas corrupisse; Aug. 69.1: condiciones quaesitas per amicos qui matres familias et adultas aetate uirgines denudarent atque perspicerent, tanquam Toranio mangone uendente.

${ }^{60}$ Tib. 45: Feminarum quoque, et quidem illustrium, capitibus quanto opere solitus sit inludere (...).

${ }^{61}$ Quotiens Ostiam Tiberi deflueret aut Baianum sinum praeternanigaret, dispositae per litora et ripas deuersoriae tabernae parabantur insignes ganeae et matronarum institorio copas imitantium atque hinc inde hortantium ut appelleret (Nero 27.3). 
Tibério para com as mulheres da aristocracia é ilustrado com o assédio a Malónia (Tib. 45), facto não mencionado por outras fontes. A infeliz é perseguida pela concupiscência do imperador, até que se refugia em casa e se trespassa com um punhal, depois de denunciar abertamente as preferências do velho, expostas depois no teatro: Vnde mora in Atellanico exhodio proximis ludis adsensu maximo excepta percrebuit, hircum uetulum capreis naturam ligurire' («Daí que, por altura dos jogos seguintes, um exódio de atelana se divulgou com a aprovação geral: "o velho bode lambe o sexo às cabras'». Mas o episódio pode ter sido moldado sobre o de Lucrécia, igualmente vítima da tirania sexual de Sexto Tarquínio ${ }^{62}$.

$O$ fundamento para certos boatos estava nas atitudes de governantes do passado histórico ou mítico. Depois de arrebatar uma matrona ao marido, Calígula terá dito que procurara apenas um matrimónio segundo o exemplo de Rómulo e de Augusto ${ }^{63}$. Mas o acto abusivo de Augusto de retirar a mulher de um cônsul do triclínio, em presença do marido, levá-la para o quarto e reconduzi-la depois ao lugar, ainda com as orelhas vermelhas e o cabelo em desalinho (Aug. 69.1), é considerado mais gravoso quando atribuído a Calígula (Cal. 36.2).

Outra particularidade é o incesto, que mancha Calígula, Nero ( $\mathrm{Cal}$. 24; Nero 28.2) e também Domiciano, que provoca a morte da sobrinha Júlia, ao obrigá-la a abortar ${ }^{64}$. O suposto incesto de Calígula com todas as irmãs, e de modo especial com Drusila (a quem ele violentara na juventude e, mais tarde, tratava publicamente como esposa), parece sugerir, segundo alguns críticos, uma tentativa de identificação com una monarquia teocrática à maneira egípcia ${ }^{65}$. Mas o boato poderá também encontrar fundamento na história de Cambises, filho de Ciro, que segundo

${ }^{62}$ Cf. Liv. 1.58. Vide R. Martin 1991: 133.

${ }^{63}$ Cal. 25.1. Cf. D.C. 59.8 .7 que the chama Cornélia Orestila (ou Orestina).

${ }^{64}$ Dom. 22. Tal relação era considerada incestuosa, pelo que também o casamento de Cláudio com a sobrinha Agripina teve de ser ratificado pelo senado: (...) taliun coniugionm, quae ad id tempus incesta habebantur (Cl. 26.3); Ducturus contra fas Agrippinam uxorem (Cl.39.2).

${ }^{65}$ Cal. 24.1. Cf. J. AJ 19.204; D.C. 59.22.6; Aur.Vict. Caes. 3.10. Vide R. Martin 1991: 331; J. Colin 1954: 408; P. Lambrechts 1953: 226-228 e n. 2. A ideia do incesto pode ser uma deformação das fontes a partir da importância que Calígula atribuía às irmãs. 
Heródoto (3.31) desposou a irmã. Uma vez que tal união não era costume entre os Persas, Cambises terá perguntado aos juízes se encontravam alguma lei que permitisse a um irmão desposar uma irmã, ao que the foi respondido que não, mas que, por outro lado, havia uma lei que permitia ao rei dos Persas fazer o que desejasse. A resposta dos juízes contém, pois, a essência do poder do tirano. $\mathrm{O}$ modelo prevalece na história que se conta de Caracala e da belíssima Júlia Domna, apresentada na Historia Augusta como madrasta do imperador: certo dia em que ela se desnudou à sua frente, ele terá dito que "quereria desposá-la, se lhe fosse lícito», ao que ela respondeu que «se ele queria, era lícito, ou ele se esquecia que, sendo imperador, ditava as leis, não as recebia?!» (Hist.Aug. Carac. 10.1-3.) ${ }^{66}$.

Tornou-se famoso o alegado incesto de Nero com Agripina (Nero 28.2) do qual Suetónio segue a versão mais hostil, enquanto Tácito pende para a opinião de Clúvio Rufo, para quem o incesto foi iniciativa dela, na mira de conservar o poder ${ }^{67}$. Parece haver uma assimilação dos crimes de Nero a modelos mitológicos que ele próprio incarnava no palco, entre outros, os papéis de Orestes matricida e o de Édipo cego (Nero 21.3). A tradição sobre Nero explora, pois, a ligação de dois crimes reais afortunados na tradição trágica: o matricídio e o incesto.

A licenciosidade inclui a homossexualidade passiva, designada por impudicitia, amiúde invocada na invectiva política. Já Cícero acusava Marco António de se prostituir (Phil. 2.44). Tais acusações parecem denotar, em Suetónio, um expediente implícito na ascensão da carreira do futuro tirano: César tem a fama de ter sido catamito de Nicomedes da Bitínia (Jul.2; 49.1; 49.4); Augusto é acusado de se ter prostituído a César e a Hírcio (Aug. 68) e Domiciano a Nerva (Dom.1.1);Vitélio, entre os prostitutos de Tibério em Cápreas, terá, deste modo, favorecido a carreira do pai (Vit. 3.2) ) $^{68}$ Otão liga-se de modo semelhante a Nero (Otho 2.2) ${ }^{69}$.

${ }^{66}$ Cf. Hist.Aug. Sev. 21.7; Eutr. 8.20; Aur.Vict. Caes. 21.1-3 e Epit.21.5; Jer. Chron. P. 213 Helm (2a ed.); Oros. 7.18.2. A ser verdade, o caso de Caracala seria ainda mais gravoso, uma vez que Júlia Domna não era madrasta, mas mãe dele. Segundo Herodiano $(4.9 .3 ; 4.13 .8 ; 5.3 .2)$, os Alexandrinos, conhecedores do grau de parentesco, chamavam-lhe Jocasta.

${ }^{67}$ Ann. 14.2. Suetónio terá seguido a versão de Fábio Rústico.

${ }^{68}$ Tac. Hist. 3.86.1, pelo contrário, afirma que Vitélio devia a sua ascensão aos méritos do pai.

${ }^{69}$ D.C. 64.8 .3 confirma a homossexualidade de Otão, mas com os favoritos de Nero; vide R. Martin 1991: 166. Segundo T. F. Carney 1968: 11-12, Suetónio 
A transgressão moral decorrente da absoluta liberdade do tirano pode resumir-se em dois pequenos capítulos da Vida de Nero (Nero 28-29): comércio carnal com rapazes de nascimento livre; concubinato com mulheres casadas; violação de um virgem vestal; projecto de casamento com uma liberta Acte; transformação de um eunuco em esposa; incesto; entrega sexual passiva a uma pessoa de categoria inferior, no caso, um liberto.

Outro aspecto da quebra das convenções é o vestuário e o aspecto do rosto $^{70}$. Exemplo paradigmático é o de Calígula, cuja indumentária aparece classificada em sugestiva gradação: Vestitu calciatuque et cetero habitu neque patrio neque ciuili, ac ne uirili quidem ac denique humano semper usus est (Cal, 52) ("Nas roupas e no calçado e no restante trajar não usou o tradicional do seu país, nem o habitual dos cidadãos, nem sequer masculino e, em suma, nem humano»). Trata-se aqui da censura da inciuilitas através do vestuário: o traje patrius e ciuilis é a toga, cujo uso Augusto procurara incentivar (Aug. 40.5). A enumeração das roupas e adornos de Calígula denuncia gostos orientalizantes, efeminados e monárquicos, de que é exemplo o uso da seda, proibida por Tibério ${ }^{71}$. Fazendo jus à sua alcunha, Calígula parece interessar-se por calçado exótico. Usa peças orientais, que, em Roma, só têm lugar no palco: as sandálias e socos (crepidae, socci), o coturno (usado pelos reis helenísticos), sinal de tirania. Além disso, enverga a couraça de Alexandre Magno. O travestismo é objecto de condenação ${ }^{72}$, bem como o uso de roupas das divindades, pois a imitação dos deuses é sinal inequívoco de inciuilitas. Ao ostentar atributos divinos, Calígula parece estar a imitar o seu bisavô Marco António que, no Oriente, se apresentou como Dioniso ${ }^{73}$; ao empunhar o raio, imitando Júpiter, parece seguir os passos de Alexandre ${ }^{74}$ e outros monarcas. Motivo de muitos

parece querer ligar, de modo especial, a homossexualidade aos tiranos. Mas o processo de caracterização não parece ser assim tão simples.

${ }^{70}$ Vide J. R. Dunkle 1967: 170; J. R. Dunkle1971: 18-19.

${ }^{71}$ Cf. Tac. Ann. 2.33.1; D.C. 57.15.1.

${ }^{72}$ Sen. Ep. 122.7: non uidentur tibi contra natura uiuere qui commutant cum feminis Hestem?

${ }^{73}$ Cf.Vell. 2.82.4; D.C. 48.39.2; Plu. Ant. 24.3

${ }^{74}$ Que assim foi representado por Apeles (Plu. De Iside 24) c em cunhagens na Babilónia. 
comentários foi o chamado "banquete dos doze deuses" no palácio de Augusto, em que o próprio imperador se disfarçou de Apolo (Aug. 70.1). O carácter efeminado de César revelava-se no uso da túnica não cintada (Jul. 45.3), hábito partilhado por Nero, cuja forma de vestir era considerada indecente. Além disso, o estilo do cabelo deste, imitação do penteado de Alexandre ou moda entre os aurigas ${ }^{75}$, tornava-se escandaloso (Nero 51).

Também explorada em exercícios retóricos era a expressão facial aterradora do tirano, acaso uma influência da expressão sanhuda da máscara dos tiranos na tragédia ${ }^{76}$. O motivo parece estar presente na notícia de que Calígula trabalhava o rosto, natura horridus ac taeter, em frente ao espelho, de forma a provocar terror ac formido (Cal. 50.1), e na nota sobre o impressionante olhar rígido de Nero ao morrer, que incute igualmente horror e formido aos presentes ${ }^{77}$.

A substância doutrinal sobre o tirano à moda grega poderá ter sido introduzida na sociedade romana através da tragédia ${ }^{78}$. Referências trágicas são por vezes usadas nas Vidas dos Césares como forma de expressar a propensão para a tirania. $O$ carácter de Calígula aparece denunciado na repetição de uma exclamação do Atreu de Ácio - 'oderint, dum metuant ${ }^{79}$ ("tenham-me ódio, desde que tenham medo") - que se tornara numa espécie de emblema da crueldade tirânica ${ }^{80}$ e que é também atribuído, com variação, a Tibério ${ }^{81}$. Observa o biógrafo, louvando-se em Cícero (Off. 3.82), que o facto de César repetir continuamente uns versos das Fenícias de Eurípides, que correspondem a uma fala de Etéocles, em que a ambição de poder é colocada à frente da justiça e do respeito pelos

${ }^{75}$ Vide K. R. Bradley 1978: 284-285.

${ }^{76}$ Cf. Sen. Con. 2.5.4.Vide J. R. Dunkle 1967: 170.

77 Nero 49.4: Atque in ea uoce defecit, extantibus rigentibusque oculis usque ad horrorem formidinemque uisentium.

${ }^{78}$ Vide J. R. Dunkle 1967: 153-154; J. R. Dunkle 1971: 12-13.

${ }^{79} \mathrm{Cal}$. 30.1. É também o Atreu de Ácio que regista o mais antigo emprego em latim do termo tyrannus. A aspiração monárquica de Calígula é também expressa (Cal. 22.1) pela citação homérica «haja um só chefe, haja um só reil» (Il. 2.204-205); e o primeiro hemistíquio do mesmo verso 204 - «não é bom que o poder esteja distribuído por muitos» - é colocado na boca de Domiciano (Dom. 12.3).

${ }^{80}$ Cf. Cic. Sest.48.102; Phil.1.14.34; Off. 1.28.97; Sen. Ira 1.20.4.

${ }^{81}$ Tib 59.2: oderint, dum probent. Vide D.W. Hurley 1993: 122. 
deuses $^{82}$, é indício de aspiração à dominatio. E Nero agrava o verso trágico

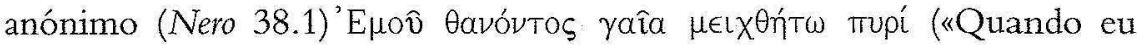
tiver morrido, seja a terra amalgamada pelo fogo») - já de si nefando, segundo Cícero e Séneca ${ }^{83}$-, com a variação da sua autoria: 'E $\mu$ ô $\zeta \hat{\omega} \nu$ To ( Enquanto eu estiver vivo!»). Que os romanos associavam o que se dizia no palco à realidade mostra-o o facto de um poeta ter sido executado, porque injuriou Agamémnon numa tragédia e Tibério se sentiu atingido $\left(\right.$ Tib. 61.3) ${ }^{84}$.

$O$ cidadão romano, cioso da sua libertas, abominava a dominatio: não aceitava submeter-se a um rex. O castigo para quem desejasse tomar para si o poder era a morte; e diversas declamationes tratavam o tema do praemium a conceder ao tiranicida ${ }^{85}$. Entre as várias explicações para a travessia do Rubicão, vem a suspeita de que César acalentava o desejo calculado da dominatio $^{86}$; e, mais tarde, várias acções e ditos são, em consonância com os critérios biográficos de análise caracterológica ${ }^{87}$, reveladores de abuso de poder, pelo que justificavam a morte do ditador ${ }^{88}$ : este tornara-se culpado de hybris ao aceitar, em vida, honras que ultrapassam a condição humana (Jul. 76.1). A mesma insolência se censura sobretudo a Calígula, que se arroga atributos divinos (Cal. 22), e a Domiciano, por se declarar dominus

82 Jul. 30.5. Eur. $P h$. 524. Cícero é o autor da versão para latim: Nam si uiolandum est ius, <regnandi> gratia / uiolandum est: aliis rebus pietatem colas. Em conformidade com o léxico político republicano, o Arpinate traduz tyrannis por regnum e eusebeia por pietas.Vide L. Canfora 2000: 153.

${ }^{83}$ Cic. Fin. 3.19.64: vox inhumana et scelerata. Sen. Cl. 2.2 .2 coloca o dito a par da referida citação do Atreu de Ácio: considero multas voces magnas, sed detestabiles, in vitam humanam pervenisse celebresque volgo ferri, ut illam: 'oderint, dum metuant,' cui Graecus versus similis est, qui se mortuo terram misceri ignibus inbet, et alia huius notae. D.C. $58.23 .4 \mathrm{diz}$ que Tibério repetia frequentemente este verso quando tratava da sua sucessão em favor de Calígula.

${ }^{84}$ O poeta será Mamerco Escauro, autor de um Atreu. Cf. Tac. Ann. 6.29.3; D.C. 58.24.3-5. Mas, segundo Tac. Ann. 6.29.6, a acusação efectiva foi de adultério com Lívia Júlia, esposa de Druso, e prática de magia.

${ }^{85}$ Vide R. Tabacco 1985: 14 ss.

${ }^{86} \mathrm{Jul}$. 30.5: Quidam putant captum imperii consuetudine pensitastisque suis et inimicorum uiribus usum occasione rapiendae dominationis quam aetate prima concupisset.

${ }^{87}$ Cf. Plu. Alex. 1.

${ }^{88} \mathrm{Jul}$. 76.1: Praegrauant tamen cetera facta dictaque eius, ut et abusus dominatione et iure caesus existimetur. 
et deus (Dom. 13.2). Tais comportamentos eram designados pela tradição como inpotentia ou arrogantia ou superbia, termos que definiam o comportamento tirânico ${ }^{89}$.

Para não incorrer na acusação de tirania, Augusto rejeita ostensivamente o apelido de dominus ${ }^{90}$ e procura demonstrar a sua ciuilitas $^{91}$. Tibério ostenta manifestações dessa virtude no início do império ${ }^{92}$. Uma vez que alguns principados acabam por degenerar numa total falta de respeito pelas leis e pelas instituições do Estado, de modo especial o senado, e sendo o carácter para os antigos algo de inato, o comedimento do período inicial dos governos daqueles Césares é explicado como uma notável capacidade de dissimulação. $\mathrm{O}$ biógrafo procura demonstrar que o carácter de Tibério é, em grande parte, determinado pela herança genética contraditória dos Cláudios (Tib. 3.1) e que Nero herdou os vícios e degenerou as virtudes dos Domícios (Nero 1.2). O pai deste último confirma que dele e de Agripina só podia nascer algo de mau para o Estado (Nero 6.1).

O comportamento tirânico gera a inveja pela situação de excepção, que se tornara topos literário como valor oposto da aurea mediocritas ${ }^{93}$, e o ódio natural contra quem detém o poder pela força ${ }^{94}$. Tibério, Calígula, Nero, Galba, Vitélio e Domiciano, segundo nos diz o biógrafo, tornam-se odiosos aos olhos dos súbditos e, consequentemente, vivem sob uma espada de Dâmocles ${ }^{95}$. O topos do medo ${ }^{96}$ é particularmente aplicado Tibério e

${ }^{89}$ Vide F. Oliveira 1986: 25.

${ }^{90}$ Aug. 53.1: Domini appellationem ut maledictum et obprobrium semper exhorruit.

${ }^{91}$ Aug. 51.1: Clementiae ciuilitatisque eius multa et magna documenta sunt.

${ }_{92}$ Tib. 26.1: Verum liberatus metu ciuilem admodum inter initia ac paulo minus quam priuatum egit. Ex plurimis maximisque honoribus praeter paucos et modicos non recepit; 57.1: (...) etiam inter initia cum adhuc fauorem hominum moderationis simulatione captaret.

${ }^{93}$ Cf. Archil. fr. 23.19-21 W; fr. 19.1-4 W; Anacreont. 8.1-4 Pr. Vide ainda Anacr. fr $361 P M G$.

${ }^{94}$ Tito é a excepção que confirma a regra: Tit. 1: (...) tantum illi ad promerendam omnium uoluntatem uel ingenii uel artis uel fortunae superfuit, et quod difficillimum est, in imperio...

${ }^{95}$ Quam inter haec non modo inuisus ac detestabilis (Tib. 63.1); Per haec terribilis cunctis et inuisus, tandem oppressus est (Dom. 14.2); Nullis tamen infensior quam uemaculis et mathematicis (Vit. 14.4); Per haec prope uninersis ordinibus offensis uel praecipua flagrabat inuidia apud milites (Gal. 16.1); Ita bacchantem atque grassantem non 
Domiciano $^{97}$, que se tornam desconfiados e se isolam: o primeiro escolhe Cápreas como refúgio pela sua inacessibilidade, afirma Suetónio ${ }^{98}$; o segundo, de quem se diz que se tornou cruel por causa do medo ${ }^{99}$, orna as paredes dos pórticos com placas de fengite, que lhe permitem vislumbrar o que se passa atrás das costas, interroga os prisioneiros a sós, em lugar secreto e segurando nas mãos as cadeias ${ }^{100}$, e condena Epafrodito, que ajudara Nero a suicidar-se (Nero 49.3), para desencorajar tal procedimento (Dom 14.4).

$\mathrm{O}$ ódio ao tirano é frequentemente expresso em panfletos ou grafitos anónimos que parecem funcionar como uma espécie de catarse para a frustração dos cidadãos (Jul. 80.2-3; Tib. 59; Nero 39.2; Dom. 13.3; 14.2). A espontaneidade das reacções à morte dos imperadores é reveladora. Recorde-se o que Suetónio nos diz sobre o contentamento do povo, depois de Tibério morrer: "uma parte gritava 'Tibério ao Tibre!», outra parte rogava à Terra mãe e aos deuses Manes que lhe não concedessem assento senão entre os ímpios; outros ameaçavam o cadáver com o gancho e as Gemónias, exasperados pela recordação da antiga crueldade e da recente atrocidade (Tib. 75.1) - reclama-se o castigo reservado aos inimigos do Estado e aos piores tiranos. Outros houve que propuseram que o «cremassem pela metade» em Atela (Tib. 75.3), seguindo, talvez, a crença de que o corpo do tirano não ardia por completo ${ }^{101}$. Vitélio, depois de

defuit plerisque animus adoriri (Cal. 56.1); Talem principem paulo minus quattuordecim annos perpessus terrarum orbis tandem destituit (Nero 40.1).

${ }^{96}$ Sobre o medo e desconfiança de Dioniso, o velho, cf. Cic. Off. 2.7.24-25 e Tusc. 5.20 .58 ss. Vide R. Tabacco 1985: 33 ss.

97 ... sed praetrepidus quoque atque etiam contumeliis obnoxius uixerit, multa indicia sunt (Tib. 63.1); ... Quare pauidus semper atque anxius minimis etiam suspicionibus praeter modum commouebatur (Dom. 14.2).

98 ... quod uno paruoque litore adiretur, saepta undique praeruptis immensae altitudinis rupibus et profundo mari[s] (Tib. 40). Ao passo que Tac. Ann. 4.67.2 acrescenta o clima temperado e a beleza do lugar.

99 ... quantum coniectare licet, super ingenii naturam inopia, rapax, metu saeuts (Dom. 3.2).

${ }^{100}$ D.C. 67.12 .5 conta o mesmo facto e acrescenta que os interrogava sozinho para evitar que outros conhecessem o conteúdo da conversà.

${ }^{101}$ Cf. Cic. Phil. 2.89-91; Plu. Sull. 38.3.Vide H. Lindsay 1995: 187. O corpo de Tibério não foi lançado ao Tibre, como sugerem F. Dupont et T. Éloi 2001: 303, mas teve exéquias públicas, em Roma, e Calígula fez o elogio fúnebre (D.C. 58.28.5). 
linchado, foi arrastado para o rio (Vit. 17.2); e era esse o destino que os cesaricidas planeavam dar ao corpo de Júlio César (Jul. 82.4). Mais tarde, o senado e o povo hão-de expressar o desejo de que o cadáver de Cómodo seja arrastado com um gancho e lançado ao Tibre ${ }^{102}$. E Heliogábalo será objecto de um ultraje ainda maior, uma vez que será lançado à cloaca e depois ao rio, ne umquam sepeliri posset (Hel.17.1-3). O método biográfico de Suetónio e os mesmos estereótipos de caracterização dos maus governantes serão amiúde empregues pelo autor da História Augusta no retrato daqueles dois Antoninos, aproximados, em vários aspectos, dos mais mal-afamados imperadores do século I, especialmente Calígula e de $\mathrm{Nero}^{103}$.

A reacção à morte de Nero é paradoxal e mostra em que medida este imperador era, ao mesmo tempo, odiado e amado. Por um lado, o gaudium público, pela libertação do domínio do tirano: a plebe corre pilleata (Nero 57.1), isto é, com o barrete característico da libertação dos escravos e das Saturnais e símbolo da abolição da tirania ${ }^{104}$. Por outro lado, há, por longo tempo, diversas manifestações secretas de pesar, tanto que, passados vinte anos, um falso Nero ainda teve grande acolhimento, sobretudo entre os Partos, o que revela a admiração que o Oriente the consagrava (Nero 57.2). As reacções à morte de Domiciano contrastam com as manifestações universais de pesar pelo trespasse ante diem de Tito (Tit. 11): a inevitável comparação dos dois irmãos prejudica o mais novo. $O$ povo acolheu com indiferença a notícia da morte do último dos Flávios; os soldados, com agravo (quiseram inclusive vingá-lo); os senadores com tanta alegria que correram para a Cúria, crivaram-no de injúrias e trataram de propor a damnatio memoriae (Dom. 23.1).

Em suma, retomadas pelo biógrafo, as características dos tiranos favorecem uma descrição verosímil para os seus contemporâneos ${ }^{105}$ - assentam certamente num fundo de verdade, enquadrado por um vocabulário

102 Corpus eius ut unco traheretur atque in Tiberim mitteretur, senatus et populus postulauit (Hist.Aug. Com.17.4).

${ }^{103}$ J. L. Brandão 2007: 133-146; C. Teixeira 2007: 229-242; R. Furtado 2007: 187-228.

${ }^{104}$ Os cesaricidas Bruto e Cássio cunharam moedas com o pileus ladeado por dois punhais. Vide B. Poulle 1997: 243-252.

${ }^{105}$ Vide F. Dupont et T. Éloi 2001: 263-323. 
tipificado e ilustrado com exemplos por vezes decalcados de situações análogas, com exageros ou distorções da realidade, operadas pelo autor ou pelas suas fontes. Suetónio inclui, nas Vidas dos doze Césares, relatos de várias proveniências e, de modo geral, não estabelece uma clara distinção entre fontes crediveis e fontes duvidosas, designadas a maior parte das vezes genericamente, por recurso a expressões como sunt qui putent, multi, alii, quidam, nonnulli.

Além das fontes, também o biógrafo deixa o seu cunho pessoal, quanto mais não seja pelos seus critérios de análise. Ao descartar a acção de Sejano ou Tigelino (retratados por Tácito com termos próprios da tirania $^{106}$ ), Suetónio imputa a Tibério e a Nero a total responsabilidade dos actos ocorridos nestes principados: deste modo, os caracteres são apresentados de forma mais unitária. Também não procura hierarquizar os factos segundo o seu relevo histórico; antes tende a ceder às versões mais romanescas, muitas vezes resultantes da calúnia ${ }^{107}$.

O principal objectivo do autor, na linha da tradição biográfica, é fazer uma caracterização completa das personagens: factos anedóticos, ditos de espírito e meros boatos contribuem para delinear o carácter e revelam-se tão ou mais importantes do que os grandes feitos heróicos (Plu. Alex 1). Ora Suetónio, ao optar pelas versões mais intensas, apresenta narrativas que podem não passar de rumores, mas que acentuam os caracteres descritos. A constante generalização e a gradação dos vícios e dos exempla, em vez da ordenação cronológica, fazem ressaltar ainda mais os traços tirânicos. Para tornar o relato consonante com a caracterização dominante do imperador em causa, o biógrafo recorre frequentemente a associações e ao emprego de expressões do tipo non abhorret a ueritate ${ }^{108}$. Do ponto de vista doutrinal, tomando como exemplo os monarcas helenísticos, todo o tirano evidenciaria à partida inciuilitas, saeuitia ou crudelitas, luxuria, rapacitas, libido exacerbada e impietas contra os deuses, contra a pátria e contra a família. E, se não apresentava estes traços, conclui-se que os dissimulava: uma forma hábil de explicar, sem entrar em contradição, o tradicional período bom de príncipes como Calígula ou Nero.

${ }^{106}$ Cf., para Sejano, Ann. 4.1; para Tigelino, Hist. 1.72.

${ }^{107}$ Vide J. Gascou 1984: 438; R. Martin 1991: 153-157.

${ }^{108}$ Cal. 12.3; nec abhorret a uero (Tib. 62.3); non abhorrentia a natura sua (Nero 43.1). 


\section{Bibliografia}

A. AlARdi (1978), "Per un'interpretazione della Domus Aurea", PP 33: 90-103.

B. BALDWIN (1979), "Nero and his mother's corpse", Mnemosyne 32: 380-381.

S. BARTSCH (1994), Actors in the audience. Theatricality and doublespeak from Nero to Hadrian. Cambridge (Mass.).

M. Blarson (1998), "Suétone et l'ekphrasis de la Domus Aurea", Latomus 57: 617-624.

K. R. Bradiey (1978), Suetonius' Life of Nero. An historical commentary. Bruxelles.

J. L. Brandão (2005), "Suetónio e o fascínio do Oriente" in F. Oliveira (coord.), Génese e Consolidação da Ideia da Europa. Vol. III: O Mundo Romano. Coimbra, 81-102.

J. L. BRANDÃo (2007), "Cómodo: outro Calígula, outro Nero", Humanitas 59: 133-146.

L. CANFORa ( $\left.{ }^{5} 2000\right)$, Giulio Cesare. Il dittatore democratico, Roma/Bari.

T. F. CARney (1968), "How Suetonius' lives reflect on Hadrian", PACA 11: 7-24.

P. CeAusescu (1973), "Caligula et le legs d'Auguste", Historia 22: 269-283.

J. R. DunkiE (1967), "The Greek tyrant and Roman political invective of the late Republic", TAPhA 96:151-171.

J. R. DunkLE (1971), "The rethorical tyrant in Roman Historiography: Sallust, Livy and Tacitus", CW 65: 12-20.

F. DuPont et T. Élor (2001), L'érotisme masculin dans la Rome antique. Paris.

R. Furtado (2007) " "Vinho novo em velhos odres»? Porque foi assassinado Marco Aurélio Antonino?", Cadmo 17: 187-228.

J. Gascou (1984), Suétone historien. Paris.

A. A. Howard \& C. N. JACKSON (1922), Index uerborum C. Suetoni Tranquili stilique eius proprietatum nonnullarum. Cambridge.

D. W. Hurley (1993), An historical and historiographical commentary on Suetonius'Life of C. Caligula. Atlanta.

P. LAMBRECHTS (1953), "Caligula dictateur littéraire”, BIBR 28: 219-232.

M. Levi (1973), Nerone e i suoi tempi. Milano.

H. LINDSAY (1995), Suetonius, Tiberius. London.

R. MARTin (1991), Les douze Césars: du mythe à la réalité. Paris.

R. MAYer (1982), "What caused Poppaea's death?", Historia 31:248-249.

J. F. MCGLEw (1993), Tyranny and political culture in ancient Greece. Ithaca and London. 
M. P. MORFord (1968), "The distortion of the Domus Aurea tradition", Eranos 66: 158-179.

F. Ourverra (1992), Les idées politiques et morales de Pline l'Ancien. Coimbra.

F. Otiverra (1995), "Biografia dos imperadores em Plínio o Antigo", Biblos 71: 67-84.

F. Olveira (1997), "La imagen del gobernante ideal en Plinio el Viejo" in J. A. Sánchez Marín, J. Lens Tuero, C. López Rodríguez (eds.), Historiografía y biografía. Madrid, 119-138.

H.-P. L'Orange (1942), "Domus Aurea - der Sonnenpalast", SO 22: 68-100.

B. Poulle (1997), "Les poignards de l'année 68-69 ", RPh 71:243-252.

G. Porta (1975), "Um Caligola dell' Historia Augusta, Commodo", Atene e Roma 20: 165-170.

R. TABACCO (1985), "Il tiranno nelle declamazioni di scuola in lingua latina": Memorie della Accademia delle Scienze Morali, Storiche e Filologiche di Torino II. Classe di Scienze Morali, Storiche e Filologiche, serie V, vol. 9. Torino, 1-141.

C. Teixeira (2007), "Os paralelos ficcionais entre a biografia de Heliogábalo na Historia Augusta e a Cena Trimalchionis do Satyricon de Petrónio", Cadmo 17: 229-242.

R.Verdière (1975), “À verser au dossier sexuel de Néron”, PP 30: 5-22.

B. H. Warmington (21999), Suetonius, Nero. London. 